POLITYKA ENERGETYCZNA - ENERGY POLICY JOURNAL

$2021+$ Volume $24+$ Issue $1+5-28$

DOI: $10.33223 / \mathrm{epj} / 133184$

Mahta Ghafarian GHADIM ${ }^{1}$, Ali FARIDZAD ${ }^{2}$

\title{
Composite energy intensity index estimation in Iran: an exploration of index decomposition analysis
}

ABSTRACT: The role of energy as a key factor in enhancing sustainable development, energy security, and economic competitiveness is a reason that has made energy efficiency trends tracking essential and is why policymakers and energy planners have focused on energy intensity and its following issues. Also, the inadequate operation of the traditional energy intensity index and the overestimation of its results turned this index into a weak one. Hence, it is necessary to employ a new index that can be decomposed and is capable of considering both monetary and physical activity indicators to offer a more accurate view of the energy intensity variation. This paper develops a Composite Energy Intensity Index by combining monetary and physical activity indicators by applying the multiplicative Logarithmic Mean Divisia Index (LMDI) in 2001-2011 to decompose the factors affecting energy intensity change and seeks to fill the gap between the EGR and CEI indices. The results of the survey demonstrate more economy-wide energy consumption reduction while using the composite energy intensity index as compared to the traditional energy intensity index; also, the results show the relatively important role of the overall structure effect. From Sectoral perspective results, both energy to GDP index (EGR) and composite energy intensity index (CEI) have shown passenger transport as

$\bowtie$ Corresponding Author: Ali Faridzad; e-mail: faridzadali@yahoo.com

${ }^{1}$ Department of Energy, Agriculture and Environmental Economics, Faculty of Economics, Allameh Tabataba'i University, Iran; ORCID iD: 0000-0002-7282-1890; e-mail: mahtaghafarian@gmail.com

2 Department of Energy, Agriculture and Environmental Economics, Faculty of Economics, Allameh Tabataba'i University, Iran; ORCID iD: 0000-0002-1777-709X; e-mail: faridzadali@yahoo.com

2021. The Author(s). This is an open-access article distributed under the terms of the Creative Commons Attribution-ShareAlike International License (CC BY-SA 4.0, http://creativecommons.org/licenses/by-sa/4.0/), which permits use, distribution, and reproduction in any medium, provided that the Article is properly cited. 
the most energy-consuming sector. The passenger transport sector reveals an urgent need for implementing appropriate policies to reduce the high energy consumption of the sector.

KEYwORDS: composite energy intensity index, energy to GDP ratio index, index decomposition analysis, logarithmic mean Divisia index, physical activity data

\section{Introduction}

Energy is one of the most important production factors in the modern world. Environmental and supply security considerations and the huge human demand for energy have contributed to many negative processes, such as environmental pressure or energy dependency (Ossowska et al. 2020). Many factors, including the clime, life habits, technological changes, and national income, may affect energy consumption. Sustainable development is the answer to anthropogenic pressure that covers all spheres of human life and activity (Ossowska et al. 2020). In order to move toward sustainable development policymakers and energy planners need a clear vision of the country's energy consumption. In this regard, according to versatile energy usage, the vital role of reducing energy consumption to diminish environmental concern and the importance of energy security has led to energy efficiency as a general solution to provide a more comprehensive insight into the country's energy intensity. Energy intensity is calculated as the ratio of total energy consumption in a region or sector to the region or sector's GDP and acts as a classical criterion to measure energy efficiency. Accordingly, energy efficiency ${ }^{1}$ is an important index, which is why policymakers and energy planners focus on producing goods and services with lower energy input to meet sustainable development and enhance economic competitiveness.

From the traditional point of view, the Energy to GDP ratio $(E G R)^{2}$ as a measure of energy intensity index is an indicator of performing energy efficiency and is one of the most common monetary-based energy efficiency indicators which measures the economy-wide energy intensity, and its inverse is taken as a measure of energy efficiency at the most aggregate level.

\footnotetext{
${ }^{1}$ Energy efficiency is a linkage between energy use and its drivers and contains a variety of aggregations from the economy-wide level, sectors, sub-sectors, final energy use, technology, and process. Energy efficiency indicators use monetary or physical indicators to measure the drivers of energy use.

2 The EGR index shows some problems from a practical viewpoint. In many developing countries, non-commercial energy sources are the dominant fuel, so the reliable data belonging to these fuels is scarce. In these countries, most of the non-monetary activities belong to the underground economy that there is no exact data about them due to the lack of appropriate statistical systems. Apart from these problems, factors like a combination of industrial activities, technological changes, energy price, substitutes of energy carriers, and changes in energy demand may affect the EGR index and need to be measured at least over one period of time, and the EGR index is incapable. Therefore, decomposition in energy intensity changes is essential. Reduction in the ratio references as less energy is used to produce economic output and this is crucial for energy and environmental goals (Bhattacharyya 2018).
} 
However, this index, apart from the merits of easy computation and interpretation, cannot be considered as a major proxy for energy efficiency. (Faridzad 2015) demonstrated that the intensity ratio is affected by factors such as the combination of industrial activities, technological changes, energy price, substitutes of energy carriers, and changes in energy demand, which can be studied at least in one duration while the EGR is incapable of estimating results in the duration. The incompatibility of the nominator and denominator of ratio and time inconsistency are other demerits of the traditional EGR index. (Ang and Goh 2018) revealed that EGR suffers from being too aggregated and overly broad in context. When the monetary values are the sole activity measure, this ratio cannot provide accurate results from the structure, activity, technological changes aspects.

While the monetary value indicators are the sole measure of activity level, decomposition results are not accurate enough. In addition, variations that occur to the commodity prices of the sector may affect energy intensity changes. This distorting effect caused by commodity prices in the sector can be removed by applying physical indicators, and better energy efficiency tracking will be evaluated in return. Using disaggregated energy consumption and a combination of monetary and physical activity indicators as the drivers of energy consumption from a bottom-up approach in a Composite Energy Intensity Index (CEI), apart from the drawbacks of complicated computation and interpretation, gains benefit from more accurate results which can better track energy efficiency than the EGR index. Also, (Ang and Goh 2018) indicated an overestimation in EGR results with monetary values; therefore, they used physical activity indicators instead and proposed that using monetary activity indicators should be bound to the sectors with no accessibility to physical activity data. Developing CEI with a combination of monetary and physical activity indicators can better track energy efficiency trends. With more complicated calculations and interpretation, the CEI index has eliminated the problem of being too aggregated which the EGR was facing. It can also provide a more accurate view of energy intensity by a combination of physical and monetary activity indicators.

Decomposing the energy intensity index is a way to achieve a more proper comprehension of energy and its future needs. The decomposition analysis ${ }^{3}$ is an accounting system with a wide range of use to distribute a change in an aggregate indicator of an order to the driver components since they drive aggregate indicator changes.

Among the reviewed literature, only a few international studies had corporate physical activity data as energy use drivers. None of the studies in Iran have ever taken physical activity indicators in their studies. (Trotta 2019) provided new insight into the contribution of energy efficiency improvements to reduce energy consumption by the LMDI method and apply physical activity data in Finland over the (2011-2015) period. The results indicate energy improvements in passenger transport, services, and agriculture sectors. (Ang and Goh 2018) seek to fill the gap between the traditional energy intensity index and the composite energy intensity index for

\footnotetext{
3 The two most widely used methods are the index decomposition analysis (IDA) and the structural decomposition analysis (SDA). The IDA, through using sectoral information, is capable of employing sub-sectors' physical and monetary data, and with available annual data, it has a distinct advantage over the SDA technique, which allows it to provide more details and act as a practical tool for planners (Ang 2006).
} 
the Canadian economy concluded the EGR index significantly overstates the energy efficiency improvement. Ang and Xu (2013) reviewed and compared two different approaches based on physical activity indicators with traditional monetary IDA in industrial energy studies. An overestimate in the traditional monetary IDA was shown. (Norman 2017) compared Activity Re-factorization (AR) approach (which uses physical activity data) with Britain's traditional monetary energy efficiency index. It demonstrated an overestimate in intensity improvements while monetary outputs were the sole measure of activity.

The following studies decomposed energy intensity in the Iranian economy by IDA methods and provided Iranian energy intensity; however, none of the reviewed literature considered the physical activity indicators and their possible influence on energy intensity ${ }^{4}$ : (Faridzad 2015) decomposed energy intensity for five Iranian energy-intensive industries by a period-wise and chained-linked analysis during 2004-2011. The intensity effect and activity effect's role were found relatively significant, and the results of the chained-linkage approach were more accurate than the period-wise approach. (Lotfi et al. 2018) concluded the activity effect as the most crucial index in factors affecting energy intensity by decomposing energy intensity in industry, transportation, agriculture sectors using a combination of the IDA and the Production Decomposition Analysis (PDA) methods.

Although many studies have been conducted on energy intensity, the former results in the context of decomposition could not represent an accurate insight into energy intensity variations to policymakers.

$\checkmark$ This study aims to decompose factors affecting the Iranian economy's energy intensity changes by introducing the CEI index for the first time in $\operatorname{Iran}^{5}$.

$\downarrow$ The former results in the decomposition context could not represent an accurate insight into energy intensity variations to policymakers since existing reports about energy indices acknowledge Iran's severe energy consumption. Iran's ministry of energy reports indicates that energy consumption increased from 4.705 in 2001 to 8.1192 million barrels of oil equivalent in 2011, which is high compared to other countries. This issue leads to high energy consumption and low efficiency in Iran. Thus, a comprehensive insight into energy intensity can help reduce environmental problems and their resulting costs.

$\downarrow$ Another aim of the current study is to compare EGR and CEI.

${ }^{4}$ Other decomposition analysis methods applied for energy intensity decomposition, for example, (Farajzadeh 2015) decomposed energy intensity for the Iranian economy by SDA. Also, some studies used econometrics models in this field. The econometrics models can measure the price effects on the quantity by estimating the elasticities. The Decomposition Analysis (DA) methods are able to provide results between the origin year and the final year but the econometrics models are unable to estimate factors between the two years as DA techniques and can only provide the average changes of the time-series variables. The physical and monetary data can be used in econometrics models with the availability of time-series data but these models face the degree of freedom problem and DA methods have merit over the economic models due to not facing the degree of freedom. (Homaie Morad et al. 2016), used econometrics model (ARDL and OLS) and (Dargahi and Biabany Khameneh 2014), used the IDA technique and econometrics model to investigate factors affecting energy intensity in the Iranian economy.

5 Since none of the previous studies examine the role of physical activity indicators on energy intensity, this study has focused on the Iranian economy as a case study. 
This study is innovative and distinct from two aspects over former manuscripts:

From the methodology aspect, the current manuscript by studying physical and monetary activity indicators' role, seeks to capture energy intensity changes that result from moving away from monetary indicators toward a composite index and examining decomposed effects. Since none of the former studies have ever considered physical activity indicators with such a detailed sectoral category, this study has great novelty against them. Apart from the mentioned goals, dividing the transport sector into two sectors with different physical activity measures and considering electricity as a separated sector with the most appropriate physical measures are other novelty of this study.

Second, it is unique from the results aspect. It aims to bold the role of physical activity indicators on sectoral results and examine previous studies' validity that relied on monetary-based decompositions. This research provides more accurate results by checking whether the same decomposed effect mentioned in previous studies is the main critical reason for an increase in sectoral energy consumption in the same studied period. For instance, (Faridzad 2015) emphasized the intensity effect as the leading runner of the rise in industrial energy consumption; however, this result can be changed by moving toward the physical-based method.

Settled aims will be followed to answer the critical question: Can introducing the CEI index offer a different view of the Iranian economy's energy intensity compared to the EGR?

With regard to the above issues, this paper is organized into four sections to answer the critical question: The second section provides a methodology discussing the LMDI method from three dimensions to choose the proper model for this research and explain the following formulae. The third section demonstrates the study results and their data references, and the last section belongs to the conclusion and recommended policies.

\section{Methodology}

IDA technique ${ }^{6}$ decomposes energy consumption into three effects: The activity effect and the structure effect measure the impact of activity and structural changes on the energy consumption level. The intensity effect measures the energy intensity changes that led to a variation in energy consumption.

In the industrial energy-consuming sector, the activity indicator often denotes by monetary value measures such as value-added. This energy intensity and its following effect are named the

\footnotetext{
6 The Laspeyres and the Divisia indices can be built based on the Index Decomposition Analysis. Using the Divisia based index due to the Laspeyres index's problems has more benefits in this study. The Arithmetic Mean Divisia Index (AMDI) and the Logarithmic Mean Divisia Index (LMDI) are two methods linked to the Divisa index. LMDI, with the ability to handle data set including zero or negative values, is perfect in decomposition preferred to the AMDI (Ang 2006)
} 
Monetary Energy Intensity and the Monetary Intensity Effect. Nevertheless, it suffers from the inability to isolate the influence on total energy consumption of changing prices, changing energy efficiency, and variation in the mix of output and acts as a weak indicator as a whole. When monetary value activity indicators estimate the IDA, the result cannot be an appropriate proxy for energy efficiency changes. While using physical activity indicators as drivers of energy use in a sector through ton or cubic meter units, the estimated energy intensity and its following effect refer to the Physical Energy Intensity and Physical Intensity Effect. This approach acts as a more accurate proxy for energy efficiency than monetary energy efficiency and will better track energy efficiency trends. Therefore, the monetary decomposed energy intensity is still too aggregate and contains some problems.

\subsection{The perspective of LMDI from three dimensions}

In this study LMDI is considered from three different dimensions (method, procedure, and indicator):

The LMDI-I versus LMDI-II, the additive approach versus the multiplicative approach, the quantity indicator versus the intensity indicator. These three dimensions will have led to the eight models as the following Table 1 and 2 .

In Table 1 and 2, abbreviations are as follows:

$E_{i}^{T}$ and $E_{i}^{0}$ denote the energy consumption of sector $i$ in the final year and each initial year, and $E$ represents economy-wide energy consumption. Also, $Q^{T}$ and $Q^{0}$ show total activity in the final and initial year. $S_{i}^{T}$ and $S_{i}^{0}$ denote the activity share of sector $i$ to the total activity in the final yearand initial year. $I_{i}^{T}$ and $I_{i}^{0}$ represent the energy intensity of sector $i$ in the final and initial year, respectively. In tables above, the factor $V$ is defined by the divison of consumed energy to activity $(-)$.

Researchers should choose the best model among the above tables based on three dimensions. Based on (Ang 2015), the quantity indicator represents the absolute energy consumption, while the intensity indicator has the notion of energy efficiency. Due to the measurement units, the intensity indicator is not a good indicator to interpret additive decomposition changes. While using additive decomposition analysis, the intensity indicator is not the right choice. Also, while using LMDI-II by multiplicative decomposition, the results of the structure effect and intensity effect for the quantity indicator and intensity indicator are the same (or very close to each other if we employ the LMDI-I decomposition approach). Still, the quantity indicator with an estimation of the extra activity effect is more informative, and researchers opt for the quantity indicator over the intensity indicator.

Whether it is additive or multiplicative, the decomposition procedure aspect is another aspect that LMDI can categorize. The difference between these two procedures relates to the results. The additive decomposition brings the physical unit results, but the results are in the indices in 
TABLE 1. Formulae for LMDI based on energy consumption decomposition

TABELA 1. Wzory dla LMDI na podstawie rozkładu zużycia energii

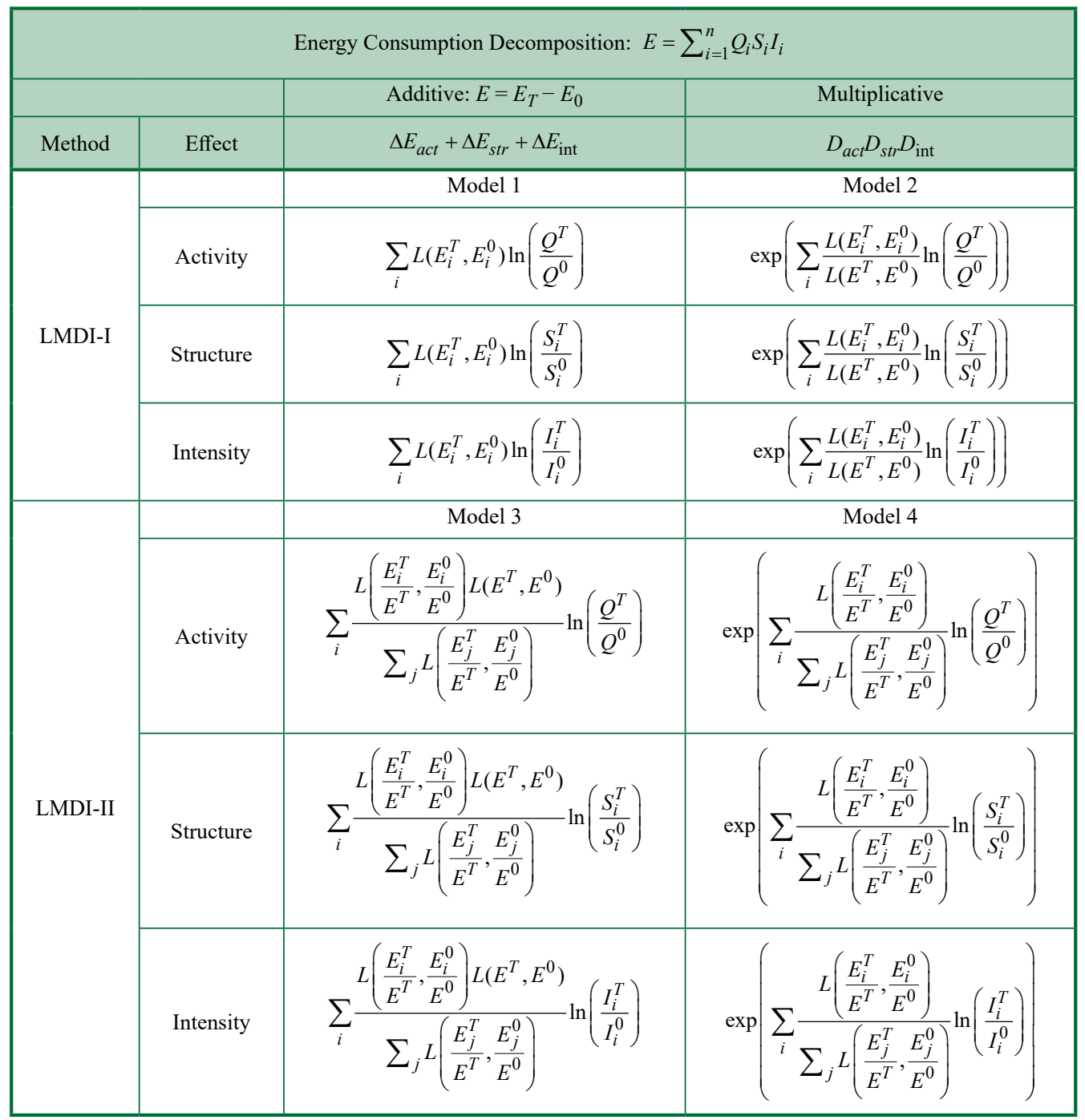

Source: based on (Ang 2015).

the multiplicative decomposition. Both approaches link to formula ${ }^{7}$ and can transfer to each other.

\footnotetext{
${ }^{7}$ For energy consumption: $\frac{\Delta E_{\text {tot }}}{\ln D_{\text {tot }}}=\frac{\Delta E_{\text {act }}}{\ln D_{\text {act }}}=\frac{\Delta V_{\text {str }}}{\ln D_{\text {str }}}=\frac{\Delta V_{\text {int }}}{\ln D_{\text {int }}}$ and for the energy intensity: $\frac{\Delta V_{\text {tot }}}{\ln U_{\text {tot }}}=\frac{\Delta V_{\text {str }}}{\ln U_{\text {str }}}=$ $=\frac{\Delta V_{\text {int }}}{\ln U_{\text {int }}}$ the additive and multiplicative approaches can be converted by the above formulas. More information is available in (Ang 2015).
} 
TABLE 2. LMDI formulae based on energy intensity decomposition

TABELA 2. Wzory LMDI oparte na rozkładzie energochłonności

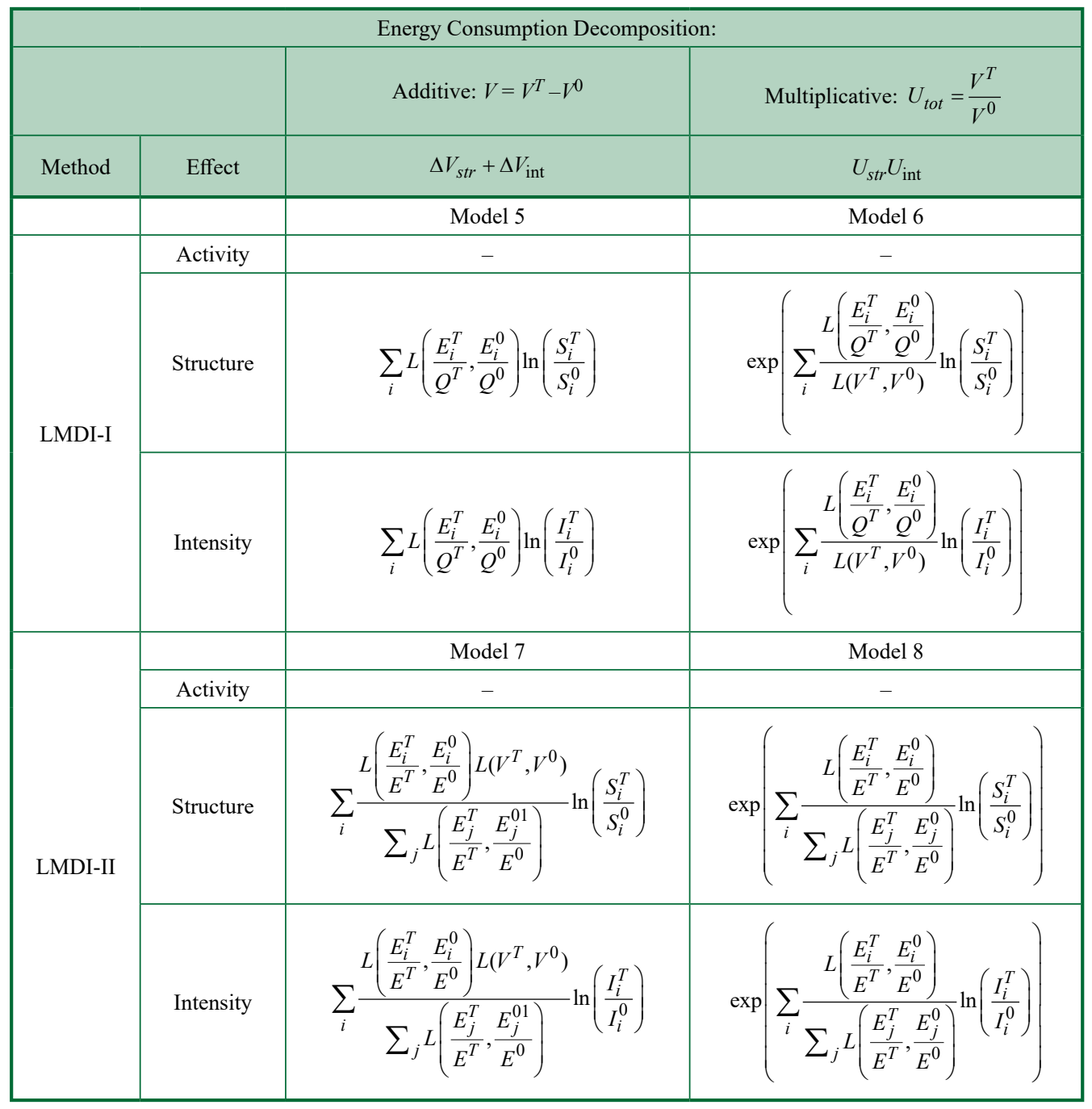

Source: based on (Ang 2015).

The third aspect goes back to choosing between LMDI-I and LMDI-II. Simplicity in employing and formulation and being capable of using the zero and negative values are the advantages of the LMDI-I and the LMDI-II. When researchers chose the aggregate indicator and decomposition procedure, the LMDI-I and LMDI-II will result in similar outcomes. 


\subsection{Calculation of Composite Energy Intensity Index}

This study uses physical activity indicators for the sectors with the available physical activity data to achieve a more accurate evaluation of energy consumption in the Iranian economy than the former studies that ignored the importance of physical activity indicators. As the three mentioned dimensions, to obtain the results in the indices and compare them with the unit value, LMDI-II with a multiplicative approach is applied. Further, to compare the traditional EGR index with the CEI index and fill the gap between these two, accessing the activity effect is essential. Nevertheless, with the compatibility of the study notion with the intensity indicator, the quantity index is used with an estimated activity effect. So, based on Table 1 model 4 is the most proper model for the present study and its aims.

The energy intensity of each sector is computed by applying the IDA method and using subsectors data. The CEI index is obtained through aggregating the energy intensity over all the sectors. In the first step, the energy consumption of sector $i$, denoted by $E_{i}$ is broken into three components:

$$
E_{i}=\sum_{j} Q_{i} \frac{Q_{i j}}{Q_{i}} \frac{E_{i j}}{Q_{i j}}=\sum_{j} Q_{i} S_{i j} I_{i j}
$$

In Eq. $1, E_{i j}$ denotes the energy consumption in the sub-sector $j$ in sector $i, Q_{i}$ is the activity ${ }^{8}$ of sector $i, Q_{i j}$ shows the activity of sub-sector $j . S_{i j}$ and $I_{i j}$ are share and energy intensity of the sub-sector $j$ in the sector $i$, respectively. The second step divides the Eq. 1 by $Q_{i}$ :

$$
\frac{E_{i}}{Q_{i}}=\sum_{j} Q_{i} \frac{Q_{i j}}{Q_{i}} \frac{E_{i j}}{Q_{i j}}=\sum_{j} S_{i j} I_{i j}
$$

The left side of Eq. 2 is the sectoral energy intensity and its relative changes from the year 0 to year $T$ is decomposed multiplicatively into the sectoral structure and intensity effect:

$$
\frac{E_{i}^{T} / Q_{i}^{T}}{E_{i}^{0} / Q_{i}^{0}}=D_{\text {tot. } . i}=D_{\text {str. } i} D_{\text {int } . i}
$$

The traditional energy intensity uses monetary measures, while the CEI index uses monetary and physical measures. Changes in the sub-sector energy intensity and the weights are critical components in the CEI index. Using different activity indicators in the EGR index and the CEI index, the combination of structure and intensity effects cannot result in the EGR index.

The divergence between the two indices is filled with the Activity Correction Effect, to demonstrate how the $A C$ effect is carried out, Eq. 1 is divided by $Y$ ( $Y$ denotes the GDP):

\footnotetext{
${ }^{8}$ Activity can be measured by monetary or physical activity indicators based on the nature of the studied sector.
} 


$$
\frac{E_{i}}{Y}=\sum_{j} \frac{Q_{i}}{Y} \frac{Q_{i j}}{Q_{i}} \frac{E_{i j}}{Q_{i j}}=\sum_{j}(A C)_{i} S_{i j} I_{i j}
$$

Left side of Eq. 4 is the sectoral energy intensity index and its relative changes, decomposed multiplicatively into the three sectoral effects:

$$
\frac{E_{i}^{T} / Y^{T}}{E_{i}^{0} / Y^{0}}=D_{\text {tot. } i}=D_{A C . i} D_{\text {str. } i} D_{\text {int } . i}
$$

Overall, changes in Eq. 5 will result in the following equation, the left side of Eq. 6 is the traditional energy intensity index, and the $D_{\text {int }}$ denotes the economy-wide CEI index. The gap between the EGR and CEI represents the overall AC effect and the whole structure effect.

$$
\frac{E^{T} / Y^{T}}{E^{0} / Y^{0}}=D_{t o t}=D_{A C} D_{s t r} D_{\mathrm{int}}
$$

By applying LMDI-II, the three effects will be carried out in the sectoral level:

$$
\begin{gathered}
D_{A C . i}=\exp \left(\sum_{j} w_{i j} \ln \left(\frac{A C_{i . T}}{A C_{i . T}}\right)\right) \\
D_{\text {str. }}=\exp \left(\sum_{j} w_{i j} \ln \left(\frac{S_{i . T}}{S_{i . T}}\right)\right) \\
D_{\text {int. } i}=\exp \left(\sum_{j} w_{i j} \ln \left(\frac{I_{i . T}}{I_{i . T}}\right)\right) \\
w_{i j}=\frac{L\left(\frac{E_{i j}^{T}}{E_{i}^{T}} \cdot \frac{E_{i j}^{0}}{E_{i}^{0}}\right)}{\sum_{j} L\left(\frac{E_{i j}^{T}}{E_{i}^{T}} \cdot \frac{E_{i j}^{0}}{E_{i}^{0}}\right)}
\end{gathered}
$$

In the last step, LMDI-II will aggregate the decomposed components, and the overall economy-wide results will be illustrated:

$$
D_{A C}=\Pi_{i}\left(D_{A C . i}\right)^{w_{i}}
$$




$$
\begin{gathered}
D_{s t r}=\Pi_{i}\left(D_{s t r . i}\right)^{w_{i}} \\
D_{\text {int }}=\Pi_{i}\left(D_{\text {int } . i}\right)^{w_{i}} \\
w_{i}=\frac{L\left(\frac{E_{i}^{T}}{E^{T}} \cdot \frac{E_{i}^{0}}{E^{T}}\right)}{\sum_{j} L\left(\frac{E_{i}^{T}}{E^{T}} \cdot \frac{E_{i}^{0}}{E^{T}}\right)}
\end{gathered}
$$

The decomposed components are compared with unit value. The result is less than unity for the CEI index references the energy efficiency improvement and energy savings.

\section{Data and Empirical Results}

\subsection{Data}

This study estimates the CEI index by the sub-sectors' data for the industry, services, freight transport, passenger transport, electricity sectors, and the economy-wide level. GDP tables with the activity classification retrieved from the Central Bank of Iran (CBI) for the years 2001 and 2011 (2004 constant prices $\left.{ }^{9}\right)$ were the source of the gathered activity data economy-wide. Energy consumption data in the economy-wide level is gathered from energy balance-sheets of Iran's Ministry of Energy for the years 2002 and 2012 ${ }^{10}$. (In this study, the year 2001 and 2011were denoted as the base year and the final year, with the unit of million-barrels crude oil equivalent ${ }^{11}$.

\footnotetext{
9 The reason for using the constant price rather than the current price relates to the demerits of the current prices that the current monetary prices cannot separate the quantity and price changes affect, and are thus unable to decompose and analyze the structural changes over time. Accordingly, within a comparative static analysis framework, the origins of the changes are not transparent. On the other hand, data based on constant prices indicate that the producer receives from the consumer for selling one unit of goods and services excluding any paid tax or received subsidies from the sold product.

10 The years 2001 and 2011 balance-sheets included primary values. Therefore 2002 and 2012 balance-sheets with the final amounts were used instead.

11 Theoretical and practical studies revealed a disproportionate change in prices at the sectoral level as a result of a change in the exchange rate and high inflation rate, therefore studying structural changes in the period of ten years would seem logical. It should be noted that obtained results for the structure effect with its value higher than unity are a sign of structural changes in Iran's economy over the shown period. Also, other conducted studies in energy intensity field considered 5 or 10 years.
} 
In the industry ${ }^{12}$ and services ${ }^{13}$, measuring the activity level with the monetary indicators (e.g., value-added) is more common. In this regard, the value-added for the years 2001-2011 (2004 constant prices) was collected from the Central Bank of Iran (CBI) to measure the activity level. Energy consumption data for the industry sector gathered from the Ministry of Energy ${ }^{14}$ for the years 2001-2011 and the method conducted by (Sadeghi et al. 2016) based on the Input-Output 2001-2011 tables. In the services sector, energy consumption data collected from the Ministry of Energy's energy balance-sheets for the years 2002 and 2012 in a million barrels of crude oil equivalent units.

In freight transport and passenger transport sectors ${ }^{15}$, activity data was retrieved from the CBI's economic time-series database for the years 2001-2011 in million-ton for freight transport and million-people for passenger transport. Energy consumption data was collected from the Ministry of Roads and Urban Development statistics for the year 2011.

In the electricity sector ${ }^{16}$ the activity data was gathered from energy balance-sheets of the Ministry of Energy for the year 2001 and Statistical Summary of Iran Electricity Industry for the year 2011 in Gigawatt-hours (GWh) and energy consumption collected from the Statistical Summary of Iran Electricity Industry for the years 2001-2011.

According to the database, the next section provides the sectoral and economy-wide EGR and CEI and tries to compare the two indices in the study levels by applying the IDA technique using the sub-sectors' collected data.

\subsection{Empirical Results}

At first, the traditional energy intensity index and the composite energy intensity index in the sectoral level in consideration of the sub-sectors data will be mentioned, and then the next part has been dedicated to the results at the economy-wide level.

\footnotetext{
12 The industry sector includes agriculture, animal husbandry, hunting, forestry, fishing, crude-oil and petroleum, manufacturing, natural gas, mining, water production distribution and transmission, and building and construction.

13 The services sector contains hotel and restaurant, monetary and financial services, educational and health services, public services, and other services.

14 Energy consumption data for agriculture, animal husbandry, fishing, forestry, crude-oil and petroleum, manufacturing, and natural gas sub-sectors gathered from the Ministry of Power balance-sheets (2002-2012) and for the mining, water production distribution and transmission and building and construction sub-sectors, extracted from the method provided by Sadeghi et al. based on energy consumption calculation in the Input-Output 2001-2011 tables.

15 The road, air, rail and sea transport intend as the sub-sectors of freight transport and passenger transport.

16 The electricity sector includes the thermal plant, gas plant, combined-cycle plant, renewable plants. Each of the four mentioned plants is a sub-category of the Ministry of Power, and renewable plants contain hydroelectric, solar, wind, diesel, and new power plants. New power plants include wind, solar, nuclear, biogas power plants.
} 


\section{Sectoral EGR and CEI}

Relative changes in the sector's energy consumption to the total GDP ratio from 2001 to 2011 resulted in the $\mathrm{EGR}_{\mathrm{i}}$ index. The sectoral EGR by applying multiplicative procedure results in three sectoral effects (activity effect, structure effect, and intensity effect) and the intensity effect represents the sectoral CEI. Table 3 shows the sectoral EGR, CEI results and their percentage of energy consumption changes in the years 2001 and 2011.

TABLE 3. Sectoral EGR and CEI results (2001-2011)

TABELA 3. Sektorowe wyniki EGR i CEI (2001-2011)

\begin{tabular}{|l|c|c|c|c|c|}
\hline & Industry & Services & $\begin{array}{c}\text { Freight } \\
\text { Transport }\end{array}$ & $\begin{array}{c}\text { Passenger } \\
\text { Transport }\end{array}$ & Electricity \\
\hline Sectoral EGR & 1.04 & 0.88 & 0.83 & 1.05 & 1.06 \\
\hline $\begin{array}{l}\text { Changes in energy } \\
\text { consumption via EGRi [\%] }\end{array}$ & 4 & -12 & -17 & 5 & 6 \\
\hline Sectoral CEI & 0.92 & 0.98 & 0.66 & 1.54 & 0.99 \\
\hline $\begin{array}{l}\text { Changes in energy } \\
\text { consumption via CEIi [\%] }\end{array}$ & -8 & -2 & -34 & 54 & -1 \\
\hline
\end{tabular}

Source: research calculation applying the Eq. 4, 7, 8, and 9.

Table 3 demonstrates that from the sectoral EGR aspect, the most increase in energy consumption per unit of GDP in 2001-2011 belongs to the electricity sector with the amount of 1.06 and 6\% growth in energy consumption from 2001 to 2011. The freight transport with the EGR equals 0.83 and has the most energy reduction in the study duration $(-17 \%)$. However, $\mathrm{CEI}_{\mathrm{i}}$ results (except passenger transport) are less than unity, and represent a reduction in energy consumption in the sectors in 2001-2011. According to the CEI results, freight transport has the most energy consumption reduction while passenger transport shows the most increase in energy consumption among the mentioned sectors.

We can understand from the Table 3 results, the EGR index and the CEI index as the two energy efficiency proxies provide different results. This issue is related to the different measurements for the activity indicators. The gap between the EGR index and the CEI index is filled by the AC effect and structure effect.

The results of the EGR index and the CEI index in each of the five mentioned sectors were discussed to gain a homogeneous comparison. Figure $1^{17}$ is dedicated to the EGR index, the CEI index, and the gap-filling between these two indices by the AC effect and structure effect.

\footnotetext{
${ }_{17}$ Different colors in the chart are to differentiate between the sectoral level and the economy-wide level.
} 


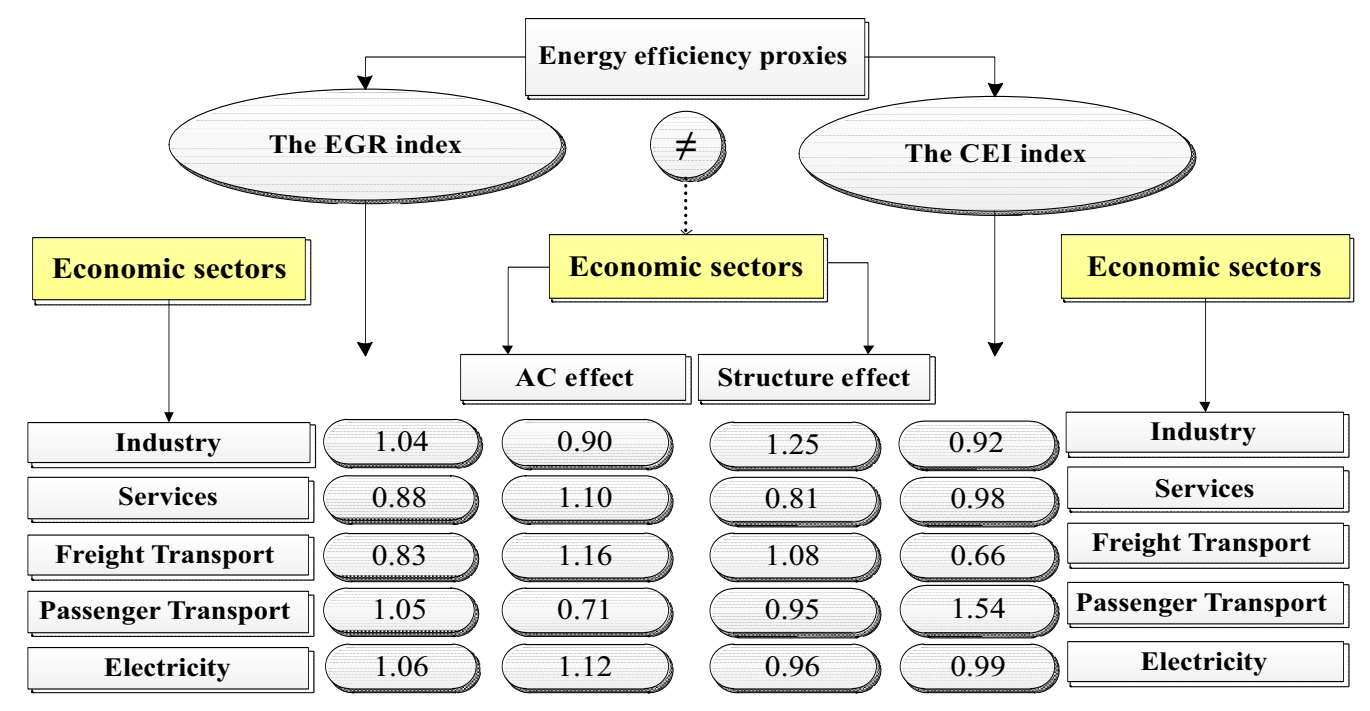

Fig. 1. The divergence between the EGR index and CEI index (2001-2011)

Source: research calculation

Rys. 1. Rozbieżność między indeksem EGR a indeksem CEI (2001-2011)

\section{Industry}

In the industry sector, Figure 1 represents the relative changes in the EGR index equals to 1.04 and a $4 \%$ increase in energy consumption due to the value higher than unity. In comparison, the CEI index with a value less than unity shows a decrease in energy consumption. The divergence between the two the EGR and CEI is filled by the AC effect and structure effect. The AC effect with the value less than unity has the share equal to $-10 \%$ in the industry sector's energy intensity variations. This reveals slower growth in the value-added than GDP. The structure effect with the share equal $25 \%$ in increasing energy consumption in the industry, which neutralizes the AC effect and the intensity effect.

Investigating the activity of the sub-sectors with the higher activity share shows a reduction in the sector's energy consumption through the $\mathrm{AC}^{\text {effect }}{ }^{18}$ and the Intensity effect. It seems that the high share of the structure effect increased energy consumption in the industry sector and resulted from the outdated production structure and the ability to renew the infrastructures in the long-run term.

\section{Services}

Figure 1 indicates a decrease equals $-12 \%$ in energy consumption through the EGR less than unity (equals 0.88 ) in the services. The sectoral CEI index with the value of 0.98 has a small

\footnotetext{
18 While measuring the sector's activity with the monetary indicators (e.g., value-added), the sectoral AC effect is a representation of the inter-sectoral structure variation. The SDA method will evaluate the inter-sectoral structure changes, based on the input-output table and require effort from this research field.
} 
difference with unity and represents $2 \%$ energy consumption reduction in the years 2001 and 2011. The higher than unity AC effect shows that the value-added services grow faster than GDP with a share of $10 \%$. The structure effect has the highest share in reducing energy consumption in the services.

The creation and enhancement of the ICT ${ }^{19}$ to develop the e-government in 2002 and electronic-banking in the year 2003 with providing the electronic services in different fields including e-commerce, e-banking, virtual education, and meetings, substituting virtual goods with physical goods, and teleworking are some of implemented practical actions that reduced the energy needs in various sub-sectors that (Dehghan Shabani and Shahnazi 2018) concluded. The results of their study can be generalized to 2001-2011 as the factors reducing energy consumption in services in the form of the CEI index and the structure effect less than unity.

\section{Freight Transport}

Comparing the EGR index and the CEI index, according to Table 1 indicates a reduction in energy consumption, which equals $-17 \%$ and $-34 \%$ respectively in $2001-2011$. The sectoral CEI index is twice as high as the sectoral EGR. The AC effect and structure effect with values higher than unity reveal an increase in energy consumption due to an increase in the sector's activity and consumption pattern. The higher than the unity of the AC effect shows faster growth in freight transport activity than GDP.

Fotros et al. (2014) indicated road transport as the most critical sub-sector in freight transport with the most energy consumption. The results also demonstrated that in Iranian industries, the low-efficiency GDP affects the sectoral activity. Struggles in importing the capital equipment and activity continuation with outdated fleets and equipment due to the high tariffs on imports and the international sanctions against Iran are the other reasons for increased energy consumption through the structure effect.

According to (Seifipour and Afroozamini 2012) and (Dorisavibehmanshir et al. 2016) results, moving toward the less energy-intensive sub-sectors ${ }^{20}$ or diminishing sub-sectors' activities ${ }^{21}$ after implementing the energy price reform in the year 2010 are the two approaches which caused a reduction in the sectoral energy intensity after which a decrease in energy consumption occurred.

\section{Passenger Transport}

The sectoral EGR index (equals 1.05) reveals a 5\% increase in passenger transport's energy consumption in 2001-2011 while by considering the physical activity indicators the CEI index represents a different evaluation, which equals a $54 \%$ increase in the sector's energy con-

\footnotetext{
19 Information and Communications Technology (ICT).

20 (Seifipour and Afroozamini 2012) indicated that the soar in energy prices reduced the difference between the road's transport cost and its real costs and enhanced rail transport competitiveness.

21 (Dorisavibehmanshir et al. 2016), demonstrated that an increase in energy prices after implementing the reforming plan of energy carriers' prices reduced energy consumption in sea transport in 2010 and 2011 due to the inverse relationship between the fuel price and sea transport demand.
} 
sumption. In passenger transport, the two indices with different values are in the same direction and demonstrate an increase in energy consumption. According to Figure 1, the AC effect and the structure effect with the values, respectively, equal to 0.71 and 0.95 with the shares of $-29 \%$ and $-5 \%$ have resulted in energy consumption reduction. The AC effect denotes that the activity in passenger transport is growing more slowly than GDP. The sectoral CEI index has neutralized the reduction based on the AC effect and the structure effect. Thus, an increase in energy consumption occurred.

Road transport is the most critical sub-sector in passenger transport. The low quality of gasoline in comparison with the international standards as the main fuel and inadequacy of the public transport system along with increasing number of vehicles are the two reasons that (Fotros et al. 2014) mentioned in their study that can be generalized to the present paper as the factors for the sectoral CEI effect higher than unity. The lack of replacing the old vehicles, implementing the emission standard plans through the vehicle technical inspection, and using the fuel with less depreciation for the engine due to gasification result in the old vehicles reduced energy consumption through the structure effect. But from the real viewpoint, these factors act as an obstacle for replacing the old vehicles and reveal a false substitution in the form of a structure effect.

\section{Electricity}

The sectoral EGR index with the value equal to 1.06 represents an increase in energy consumption equal to $6 \%$, from 2011 (the final year) to 2001 (the origin year). The CEI index is close to unity (equals 0.99 ) and reveals a low reduction in the sector's energy consumption by employing physical activity indicators. The higher than unity AC effect neutralized the structure effect, and the intensity effect and an increase in energy consumption in the sectoral EGR occurred.

Plant efficiency is the most effective factor in the electricity industries' efficiency. Based on (Pourkazemi and Heydari 2002), the combined-cycle plants and gas plants have the most and the least efficiency among the mentioned plants in this paper, and (Sadraei Javaheri and Ostadzad 2014) indicated an enhancement in the hydro-electric plants and thermal plants' efficiency. Based on the mentioned studies, moving toward more efficient plants in 2001-2011 is referenced. Figure 2 compares the variation of electricity sub-sectors activity share in 2001-2011.

Figure 2 reveals an increase in the activity share of the combined-cycle and renewable plants as the two plants with higher efficiency and a decrease in the gas plant activity share (the plant

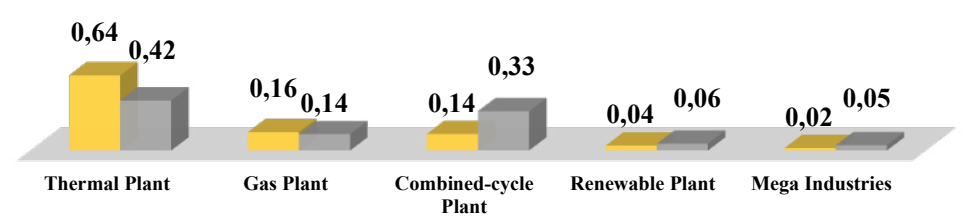

Activity share of sub-sectors from total sector's activity ${ }^{-1 c t i v i t y ~ s h a r e ~ o f ~ s u b-s e c t o r s ~ f r o m ~ t o t a l ~ s e c t o r ' s ~ a c t i v i t y ~}$

Fig. 2. Variation of electricity sub-sectors activity shares (2001-2011)

Source: research calculation

Rys. 2. Zmiana udziału działalności podsektorów energii elektrycznej (2001-2011) 
with lower efficiency). The variation in the activity share of plants from 2001 to 2011 led to a more efficient structure and diminished the electricity sector's energy consumption through the structure effect. The structural changes in power plants result in less than unity sectoral energy intensity and faster growth in the electricity sector's activity than GDP through the greater than unity AC effect.

\section{Overall EGR and CEI}

According to the 2001 and 2011 database, Iran's total energy consumption increased from 705.80 to 1184.60 million barrels of crude oil equivalent (Mboe), while its GDP grew from 1279192.98 to 2157934.13 billion rials (with the 2004 constant price). The energy-GDP ratio for 2001 and 2011, respectively, equals 55.175 and 54.895 boe per billion rials GDP. The 2011 EGR index (normalized to 1 with the 2001 EGR) is 0.99 . Table 5 demonstrates the economy-wide EGR index.

TABLE 4. Economy-wide EGR index and normalized amount (percentage of changes) (2001-2011)

TABELA 4. Ogólnogospodarczy indeks EGR i znormalizowana wielkość (procent zmian) (2001-2011)

\begin{tabular}{|l|c|c|}
\hline & 2001 & 2011 \\
\hline Economy-wide EGR index & 55.175 & 54.895 \\
\hline Normalize amount to 1 with 2001 EGR & 1 & 0.99 \\
\hline Changes in normalized amount [\%] & & -1 \\
\hline
\end{tabular}

Source: research calculation applying formulae (6).

Table 4 indicates that the 2011 EGR is 1\% less than in 2001. It shows that in 2011, 1\% less energy is required to produce one billion Rials GDP than in 2001.

By applying LMDI-II through the formulas (11), (12), and (13), the EGR index decomposed into the intensity effect, $\mathrm{AC}$ effect, and structure effect. Aggregation of sectoral intensity effects results in the economy-wide CEI index. The CEI index is 0.95 in this study and reveals a $-5 \%$ reduction in energy consumption. The EGR index and CEI index results illustrate that the gap between the two indices discussed in the previous step remains. The AC effect and structure effect will fill the gap between the two indices. Figure 3 represents the economy-wide results.

The overall AC effect and structure effects bridge the divergence between the EGR index and the CEI index. The overall AC effect has a small difference with unity and reduced energy consumption with a share of $-1 \%$. The structure effect equals 1.06 and had the highest share (equals 6\%) in an increase in energy consumption in 2001-2011.

Figure 4 demonstrates the percentage of changes in the EGR index and distribution of the $\mathrm{CEI}$ index, AC effect, and structure effect in the mentioned sectors and the economy-wide level.

Figure 4 represents the following inferences: In the industry sector, in terms of absolute values, the reduction in energy consumption through the CEI index (equals $-8 \%$ ) is twice as high as the increase in the energy consumption resulting from the EGR index (equals $4 \%$ ). In services, 


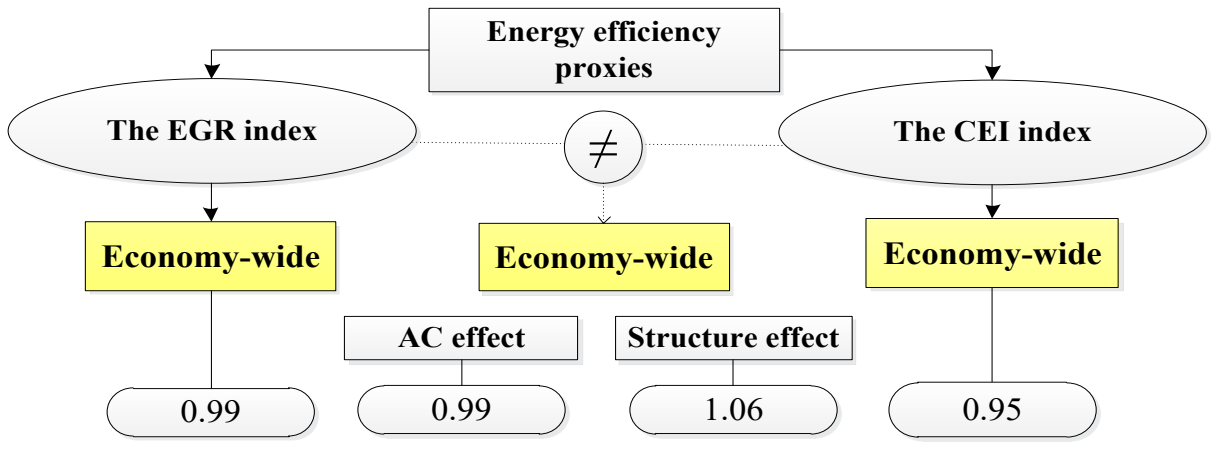

Fig. 3. Economy-wide results (2001-2011)

Source: research calculation and applying formulas (6), (11), (12) and (13)

Rys. 3. Wyniki dla całej gospodarki (2001-2011)

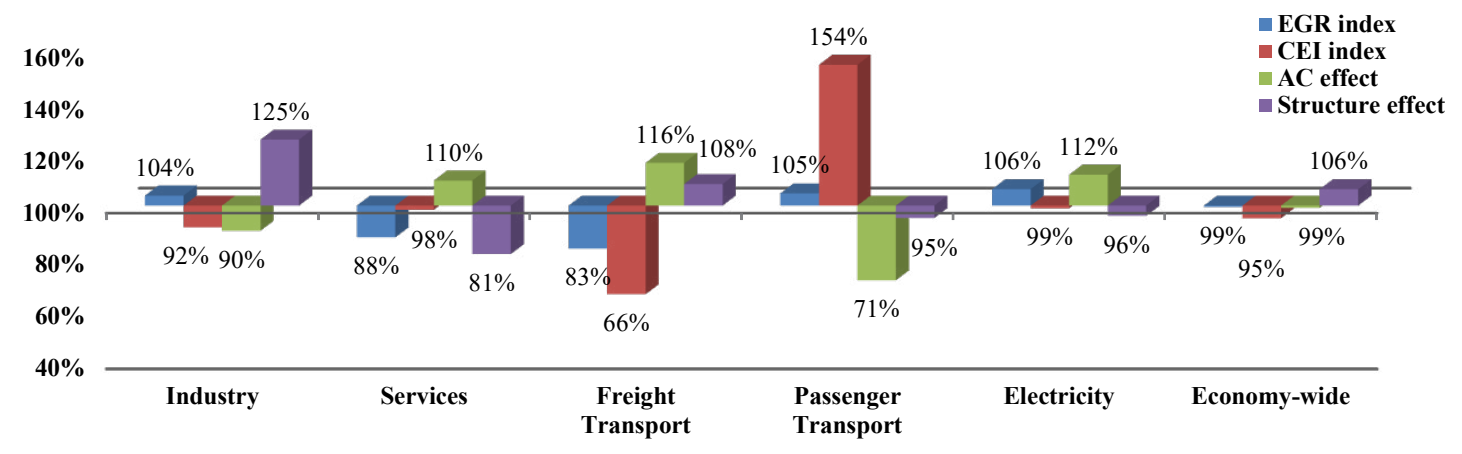

Fig. 4. Changes in the EGR index and the distribution of the studied effects in the sectoral level and economy-wide (2001-2011)

Source: research calculation

Rys. 4. Zmiany wskaźnika EGR i rozkład badanych efektów na poziomie sektorowym i ogólnogospodarczym (2001-2011)

the EGR index, CEI index, and the structure effect with different shares are in the same direction (equals $-12 \%,-2 \%$ and $-19 \%$ respectively), and the $\mathrm{AC}$ effect with the share equals $10 \%$, increased services' energy consumption. In freight transport, the CEI index reveals a reduction in energy consumption twice as high as the EGR index. The AC effect and the structure effect increase energy consumption with a higher share for the AC effect. In passenger transport, the EGR index and the CEI index have shares equal to $5 \%$, and $54 \%$ in energy consumption increases with the higher share for the CEI index. In electricity, the EGR index with the share equals and $6 \%$ has a role in energy consumption increase, and the CEI index with the share equals $-1 \%$ caused a reduction in energy consumption. The AC effect has a higher share than the structure 
effect on electricity. In the economy-wide, the EGR index and the CEI index have a role in energy consumption reduction with the shares equal to $-1 \%$ and $-5 \%$.

Use the "Insert Citation" button to add citations to this document.

\section{Conclusions and Policy recommendations}

This study decomposed the energy intensity variation using a combination of the monetary and the physical activity indicators through applying LMDI-II (with a multiplicative procedure) in the Iranian economy. In the next step, the study compared the EGR index and the CEI index in the sectoral and economy-wide level in 2001-2011.

The results indicated a greater reduction in energy consumption in the CEI index in consideration of the physical activity indicators. The EGR index showed the total variation in energy consumption equal to $-1 \%$, and the structure effect had the highest share (equals $6 \%$ ) among decomposed factors, which neutralized the reduction that arose from the CEI index and the AC effect in 2001-2011.

The previously conducted studies to investigate Iran's energy intensity relied on monetary-based energy intensity in economy-wide and sectoral studies. While (Lotfi et al. 2017) showed that the structure effect was the main contributor to the rise in energy consumption in the transport sector via monetary values, they do not pay attention to the differences between cargo and passenger transport. Dividing the transport sector into two separate sectors: passenger transport and freight transport, as they have different physical activity indicators, is one of the achievements of this paper. This division resulted in more accurate results and better instruments for policymakers and in passenger transport and freight transport, the intensity effect and structure effect increased energy consumption. We obtained different industry sector results than previous studies on this sector by taking physical activity indicators into account. The implemented procedure revealed that the structure effect was the most significant reason in increasing sectoral energy intensity; meanwhile (Faridzad 2015), by applying monetary indicators, emphasized the role of the activity effect and intensity effect. According to the reality of the changes which occurred in the Iranian economy, outdated structures were a critical reason for high energy consumption in the industry, which is compatible with the physical-based results. Also, extracting the electricity sector from industry and studying with physical activity indicators that are more compatible with the nature of the electricity sector was the other novelty of the current manuscript compared to previous papers. Three effects showed that this sector can impose proper policies to reduce the growing energy consumption, especially from the activity effect. Therefore, by applying more physical activity indicators consistent with sectors' nature, the results would be more accurate and reliable.

Passenger transport had a high energy consumption from the two indices' viewpoint and revealed a drastic need for appropriate policies in the studied period. In passenger transport, 
road transport was the most critical sub-sector. The implementation of the policies include the change in emissions' standards to higher standards, the strict implementation of vehicle technical inspection, and the appropriate tax system by higher taxes on outdated vehicles or incentive plans, will increase the demand for new vehicles and may encourage the automotive industries to produce vehicles with modern technologies as an essential step. These steps together may result in a decrease in the average age of vehicles in $\operatorname{Iran}^{22}$.

Also, results represent that in industry and electricity, the EGR index and the CEI index were in the opposite direction, and scholars should use the results of the two indices as complementary. The EGR index provided a general evaluation of energy intensity variation of the sector or the economy-wide level. Meanwhile, it was not clear that the changes from which effect or side have occurred. The CEI index in companion with the AC effect and the structure effect resulting from the study method determined the changes' origin accurately.

In industry, after implementing the energy price reforms in Iran, renewing and investing in replacing the outdated technologies found its economic justification ${ }^{23}$. In the electricity sector, managerial inefficiency was a reason for the higher than unity AC effect. Changing the managerial atmosphere and imposing critical observation on managers' operation can reduce the AC effect and energy consumption in electricity in the future.

To answer the critical question of this study, results demonstrated that apart fro the merits, using sole monetary activity measured through the the EGR index include: the ease of calculation and interpretation, and extensive international use is too aggregate and overly broad in context. In other words, the EGR index, by measuring total activities in value-added, is not capable of providing an accurate evaluation of the country's economic activities and energy intensity to policymakers. Despite the demerits of being complicated in the calculation and interpretation, the CEI index uses disaggregated energy consumption and a combination of physical and monetary activity can provide a complete evaluation of energy intensity in the Iranian economy. By considering both EGR and CEI results, complementary goals can be followed. The CEI index will better track the national energy efficiency, and the EGR index is more suitable for international comparisons. It is necessary to note that the CEI will provide a more accurate evaluation of energy intensity for energy planners and policymakers with its more detailed results.

\section{References}

ANG, B.W. 2004. Decomposition analysis for policymaking in energy: Which is the preferred method? Energy Policy 32(9), pp. 1131-1139, DOI: 10.1016/S0301-4215(03)00076-4.

ANG, B.W. 2006. Monitoring changes in economy-wide energy efficiency: From energy - GDP ratio to composite efficiency index. Energy Policy 34(5), pp. 574-582, DOI: 10.1016/j.enpol.2005.11.011.

\footnotetext{
22 Also, enhancement in gasoline efficiency as the most used fuel in passenger transport is another helpful move that can result in a reduction of Iran's energy consumption.

23 In this regard removing the international sanctions against Iran, ease in importing capital equipment, and offering facilities to renew the industries' structure are essential factors to reduce energy consumption.
} 
ANG, B.W. 2015. LMDI decomposition approach: A guide for implementation. Energy Policy 86, pp. 233-238, DOI: 10.1016/j.enpol.2015.07.007.

ANG, B.W. and GoH, T. 2018. Bridging the gap between energy-to-GDP ratio and composite energy intensity index. Energy Policy 119(April), pp. 105-112, DOI: 10.1016/j.enpol.2018.04.038.

ANG, B.W. and XU, X.Y. 2013. Tracking industrial energy efficiency trends using index decomposition analysis. Energy Economics 40, pp. 1014-1021, DOI: 10.1016/j.eneco.2013.05.014.

Appropriate taxes and incentives do affect purchases of new cars 2018. European Environment Agency.

AsAdi et al. 2015 - AsAdi, Z., ABbasi, E. and SalaHI, J. 2015. Factors Affecting Energy Intensity of Iranian Industrial. Islamic Azad University-Central Tehran Branch.

BhatTacharyya, C. 2018. Energy Economics: Concepts, Issues, Markets and Governance. Translated by Faridzad A. Leicester: Springer.

CAHILl, C.J. and BRIAN, P.O. 2012. Combining physical and economic output data to analyse energy and $\mathrm{CO}_{2}$ emissions trends in industry. Energy Policy 49, pp. 422-429, DOI: 10.1016/j.enpol.2012.06.041.

Chontanawat et al. 2019 - Chontanawat, J., Wiboonchutikula, P. and Buddhivanich, A. 2019. An LMDI decomposition analysis of carbon emissions in the Thai manufacturing sector. Energy Reports 6 , pp. 705-710, DOI: 10.1016/j.egyr.2019.09.053.

Dargahi, H. and Biabany Khameneh, K. 2016. Determinant of price and income factors, and efficiency in Iran's energy intensity. Journal of Economic Research 2(51), pp. 384-355.

Dehghan Shabani, Z. and ShahnaZi, R. 2018. Energy consumption, carbon dioxide emissions, information and communications technology, and gross domestic product in Iranian economic sectors: A panel causality analysis. Energy 169, pp. 1064-1078, DOI: 10.1016/j.energy.2018.11.062.

Dorisavibehmanshir et al. 2016 - Dorisavibehmanshir, R., Najimeydani, A., Khodaparastmashahdi, M. and Salehnia, N. 2016. Estimating The Factors Affecting Energy Demand in Sea Transport Using Econometrics methods (Case study: General Administration of Ports and Khorramshahr maritime). The Journal of Transportation Research 13(4), pp. 1-16.

economic time series data (n.d.). Central Bank of the Islamic Republic of Iran.

Energy balance-sheet (n.d.). The Iran's Ministry of Power.

Energy balance-sheet (2002-2012) (n.d.). The Iran's Ministry of Power.

FARAJZADEH, Z. 2015. Energy Intensity inIranian Economy: Determining components and factors. Journal of Iranian Energy Economics 15(4), pp. 43-86.

FARIDZAD, A. 2012. Investigating the capability and validity of using input-output table tables during the structural changes in Iranian economy. Islamic Parliament Research Center of The Islamic Republic of IRAN, pp. 1-28. [Online] https://rc.majlis.ir/fa/report/show/828482 [Accessed: 2020-12-05].

FARIDZAD, A. 2015. Energy Intensity Decomposition Analysis in Iranian energy Intensive Industries by Logarithmic Mean Divisia Index with focus on Period-wise and Chaind- linked Analysis. Journal of Iranian Energy Economics 15(4), pp. 87-117.

Fotros, J. and BARATY, M. 2010. Decomposition of $\mathrm{CO}_{2}$ Emissions of Iranian Transport Sector in Sub-sectors and Component Fuels An Application of Decomposition Analysis. Scientific Research Quarterly Applied Economics in Iran 6(2), pp. 83-64.

Fotros et al. 2014 - Fotros, M., SAhraie, R. and Yavari, M. 2014. Estimating the Energy Demnd Function in Iran's road transport (1978-2013). Quarterly Journal of the Macro and Strategic Policies 2(7), pp. 23-42.

Geravand et al. 2013 - Geravand, S., Mehregan, N., Sadeghi, H. and Malekshahi, M. 2013. Evaluation of energy efficiency in the petroleum industry in Iran. The Journal of Economic Policy 10(5), pp. $57-74$.

Homaie Morad et al. 2016 - Homaie Morad, T., Khorsandi, M. and Ghasemi, A. 2016. Analyzing the Factors Affecting Energy Intensity in Iran with Emphasis on the Role of Implementing the Policy of Making Targeted Subsidies. Allameh Tabataba'i University. 
Hosseini, K. and Stefaniec, A. 2019. Efficiency assessment of Iran's petroleum refining industry in the presence of unprofitable output: A dynamic two-stage slacks-based measure. Energy 189, pp. 1-12.

Kafaie, S.M.A. and Nejadaghaeianvash, P. 2017. Identifying the factors affecting energy efficiency in the Iranian economy. Quarterly Energy Economics Review 52(13), pp. 1-34.

KhaliliAraghi et al. 2012 - KhaliliAraghi, M., Sharzeie, G. and Barkhordari, S. 2012. Decomposition Analysis of Carbon di oxide emssion. Journal of Ecology 61(38), pp. 93-104.

Lotfi et al. 2018 - LotFi, S., FARIDZAD, A. and Ali Asghar, S. 2018. Decomposition of Energy Intensity of Iranian Economic Sectors: Index Decomposition Analysis Approach Combine with Production-Theoretical Decomposition Analysis. Journal of Energy Planning and Policy Research 85(26), pp. 151-187.

Moghaddasi, R. and ANOUSHE POUR, A. 2016. Energy consumption and total factor productivity growth in Iranian agriculture. Energy Reports Journal 2, pp. 218-220.

Moshiri, S. 2020. Consumer responses to gasoline price and non-price policies. Energy Policy 137 (September), 111078, DOI: 10.1016/j.enpol.2019.111078.

Norman, J.B. 2017. Measuring improvements in industrial energy efficiency: A decomposition analysis applied to the UK. Energy 137, pp. 1144-1151, DOI: 10.1016/j.energy.2017.04.163.

Ossowska, L.J. and JANISZEwSKA, D.A. 2020. Toward sustainable energy consumption in the European Union. Polityka Energetyczna - Energy Policy Journal 23(1), pp. 37-48.

Pourabadellahankavich et al. 2015 - Pourabadellahankavich, M., Panahi, H., Shahryar, S. and SalehiAbar, K. 2015. Decomposition of Factor Affecting Energy Consumption Changes in Irans' Industrial Sub-Sectors. Quarterly Journal If Applied Theories of Economics 4(2), pp. 49-70.

Pourkazemi, M. and Heydari, K. 2002. Using Data Envelopment Analysis (DEA) in Evaluating the Efficiency of Thermal Power Plants. Journal of Management Research in Iran 6(1), pp. 35-54.

RANJBARI et al. 2018 - RANJBARI, F., HEYDARI, E. and Parsa, H. 2018. The study of factors affecting changes in carbon dioxide emissions in selected economic sectors over the years (1996-2014 with the LMDI Index Decomposition Analysis aapproach). National Conference on Management, Economics and Resistance Economics. [Online] https://www.tpbin.com/article/69678 [Accessed: 2020-12-15].

Report on the Iran's economic condition, gross domestic product and cost 2007. Central Bank of the Islamic Republic of Iran, chapter 2, pp. 1-16. [Online] https://www.cbi.ir/simplelist/6746.aspx [Accessed: 2020-12-15].

SADRAEI JAVAHERI, A. and OstADZAD, A.H. 2014. Estimating Efficiency of Thermal and Hydroelectric Power Plants in Iranian Provinces. Iranian Journal of Economic Studies 3(2), pp. 19-42, DOI: 10.22099/ IJES.2014.3668.

SAdeghi et al. 2016 - SAdeghi, N., ZABihi, Z. and MostaeliParsa, M. 2016. Concept of iranian economic sectors 3. Estimation of energy consumption and $\mathrm{CO}_{2}$ emmision in economic-sectors. Islamic Parliament Research Center Of The Islamic Republic Of IRAN, pp. 1-67.

Seifipour, R. and Afroozamini, F. 2012. Effect of Increase in Energy Price on The Rail Demand and Its share from ground transport. Journal of Transportation Engineering 2(4), pp. 315-324.

Statistical Summary of Iran Electricity Industry (2001-2011) (n.d.). Electric Power Industry Statics, Tavanir.

SzÉP, T.S. 2013. Eight Methods for Decomposing the Aggregate Energy Intensity of the Economic Structure. Club of Economics in Miskolc' 9(1), pp. 77-84.

The Statistics of the Ministry of Roads and Urban Development 2011. [Online] http://ifco.ir/images/97/ hamlonaghl/TransportationBook90.pdf [Accessed: 2021-01-15].

Time series of Iran's national account (2001-2011). (n.d.). Central Bank of the Islamic Republic of Iran.

TrotтA, G. 2019. Assessing energy efficiency improvements and related energy security and climate benefits in Finland: An ex post multi-sectoral decomposition analysis. Energy Economics 86, DOI: /10.1016/j.eneco.2019.104640. 
Valizadeh et al. 2017 - VAlizadeh, A., SAdeghi, N. and AkhaVAn, B. 2017. 2001-2006 Input-Output table with constant price (data base and calculation method). Islamic Parliament Research Center Of The Islamic Republic Of IRAN, pp. 1-31. [Online] https://rc.majlis.ir/fa/report/show/1049215 [Accessed: 2021-01-20].

WANG et al. 2017 - WANG, H., ANG, B.W. and Su, B. 2017. Assessing drivers of economy-wide energy use and emissions: IDA versus SDA. Energy Policy 107(April), pp. 585-599, DOI: 10.1016/j. enpol.2017.05.034.

ZhANG et al. 2019 - ZhANG, X., Su, B., YANG, J. and Cong, J. 2019. Index decomposition and attribution analysis of aggregate energy intensity in Shanxi Province (2000-2015). Journal of Cleaner Production 238.

Zhou et al. 2019 - Zhou, X., Zhou, D., WANG, Q. and Su, B. 2019. Who shapes China's carbon intensity and how? A demand-side decomposition analysis. Energy Economics 85, DOI: 10.1016/j.eneco.2019.104600.

\section{Oszacowanie zagregowanego wskaźnika energochłonności w Iranie: badanie na temat analizy rozkładu wskaźników}

\section{Streszczenie}

Energia jest kluczowym czynnikiem w procesie wzmacniania zrównoważonego rozwoju, bezpieczeństwa energetycznego i konkurencyjności gospodarczej i z tego powodu śledzenie trendów w zakresie efektywności energetycznej jest niezbędne. Dlatego też decydenci i planiści zajmujący się problemami energii poświęcają dużo uwagi energochłonności i związanym z nią kwestiom. Ale tradycyjny wskaźnik energochłonności nie stanowi właściwej miary i często prowadzi do przeszacowania wyników, co powoduje, że wskaźnik ten stał się mało przydatny.

W związku z tym konieczne jest zastosowanie nowego wskaźnika, który można rozłożyć i który jest w stanie uwzględnić zarówno wskaźniki pieniężne, jak i wskaźniki aktywności fizycznej, aby zapewnić dokładniejszy obraz zmian energochłonności.

W niniejszym artykule opracowano zagregowany wskaźnik energochłonności, który łączy wskaźniki pieniężne i wskaźniki aktywności fizycznej, stosując multiplikatywny logarytmiczny średni indeks Divisia (Logarytmic Mean Divisia Index - LMDI) w latach 2001-2011 w celu dekompozycji czynników wpływających na zmianę energochłonności i stara się wypełnić lukę między wskaźnikiem udziału energii w PKB (EGR) a złożonym wskaźnikiem energochłonności (CEI).

Wyniki badania wskazują na większą redukcję zużycia energii w całej gospodarce przy zastosowaniu zagregowanego wskaźnika energochłonności w porównaniu z tradycyjnym wskaźnikiem energochłonności. Wyniki pokazują również relatywnie ważną rolę ogólnego efektu struktury.

Z perspektywy sektorowej, zarówno wskaźnik energii do PKB (EGR), jak i złożony wskaźnik energochłonności (CEI) wykazały, że transport pasażerski jest sektorem najbardziej energochłonnym. Sektor 
transportu pasażerskiego ujawnia pilną potrzebę wdrożenia odpowiedniej polityki w celu zmniejszenia wysokiego zużycia energii w tym obszarze.

SLOWA KLUCzowE: zagregowany wskaźnik energochłonności; wskaźnik relacji energii do PKB; analiza rozkładu indeksów; logarytmiczny średni indeks Divisia; dane dotyczące aktywności fizycznej 